\title{
Non-oak native plants are main hosts for sudden oak death pathogen in California
}

\author{
Kelly Ivors \\ Patricia E. Maloney \\ Daniel Hüberli \\ Steven T. Koike \\ David M. Rizzo
}

The finding of Phytophthora ramorum - the pathogen that causes sudden oak death in four California native trees - on rhododendron in Europe led us to hypothesize that its host range in California's natural forests was much greater than previously suspected. In addition to the affected oak species, we have now identified an additional 13 species from 10 plant families that act as hosts for $\mathrm{P}$. ramorum in California. Our data indicates that nearly all of the state's main tree species in mixedevergreen and redwood-tanoak forests - including the coniferous timber species coast redwood and Douglas fir - may be hosts for P. ramorum. The broad host range of $\mathrm{P}$. ramorum, the variability of symptoms among different hosts and the ability of the pathogen to disperse by air suggests that it may have the potential to cause long-term, landscape-level changes in California forests.

T nown as "sudden oak death" in the popular press, Phytophthora ramorum (Phylum Oomycota) is a recently described plant pathogen that causes a deadly canker disease of tanoak, coast live oak, California black oak and Shreve's oak in California and Oregon (Rizzo et al. 2002b; Goheen et al. 2002). This disease has reached epidemic proportions in oak forests along approximately 185 miles (300 kilometers) of the Central Coast of California during the past 7 years
Matteo Garbelotto Jennifer M. Davidson
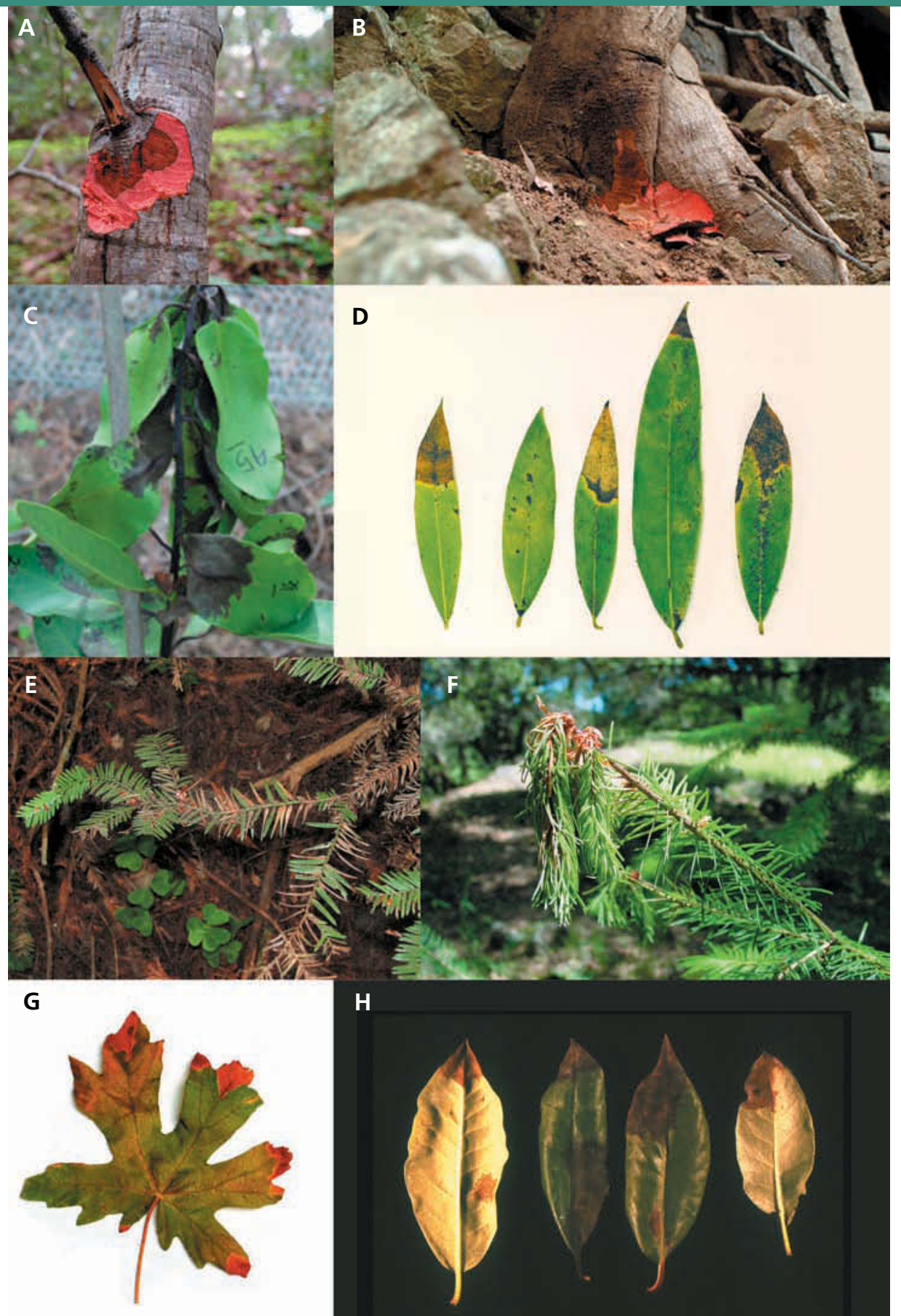

H

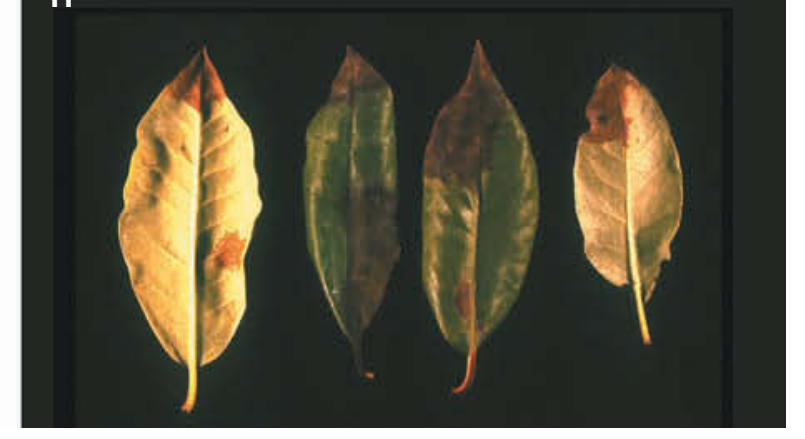

Symptoms of infection by Phytophthora ramorum on various hosts in California forests include: (A) tanoak with phloem canker on main trunk, (B) stem canker on tanoak stops at the soil line, (C) madrone with foliar and stem lesions, (D) bay laurel/Oregon myrtle with leaf-tip necrosis, (E) coast redwood with needle necrosis on understory sapling,

(F) Douglas fir with tip wilting due to branch cankers, (G) big leaf maple with marginal leaf scorch, and $(\mathrm{H})$ rhododendron showing foliar lesions. 
TABLE 1. Known hosts of Phytophthora ramorum in California,

plant part infected and original detection method

\begin{tabular}{lll}
\hline Detection & Plant part & method \\
Host: common name, species & infected & PCR \\
\hline Bay laurel/Oregon myrtle, Umbellularia californica (Lauraceae) & Leaves & PCR \\
Big leaf maple, Acer macrophyllum (Aceraceae) & Leaves & Culture \\
California black oak, Quercus kellogii (Fagaceae) & Main stem & PCR \\
California buckeye, Aesculus californica (Hippocastanaceae) & Branches, leaves & Culture \\
Coast live oak, Quercus agrifolia (Fagaceae) & Main stem & PCR \\
Coast redwood, Sequoia sempervirens (Taxodiaceae) & Branches, leaves & PCR \\
Coffeeberry, Rhamnus californica (Rhamnaceae) & Branches, leaves & Culture \\
Douglas fir, Pseudotsuga menziesii (Pinaceae) & Branches, leaves & Culture \\
Evergreen huckleberry, Vaccinium ovatum (Ericaceae) & Main stem, branches, leaves & PCR \\
Honeysuckle, Lonicera hispidula (Caprifoliaceae) & Leaves & PCR \\
Madrone, Arbutus menziesii (Ericaceae) & Branches, leaves & PCR \\
Manzanita, Arctostaphylos manzanita (Ericaceae) & Branches, leaves & Culture \\
Ornamental rhododendron, Rhododendron sp.1 (Ericaceae) & Branches, leaves & PCR \\
Rhododendron, Rhododendron macrophyllum (Ericaceae) & Branches, leaves & Culture \\
Shreve's oak, Quercus parvula var. shrevei (Fagaceae) & Main stem & Culture \\
Tanoak, Lithocarpus densiflorus (Fagaceae) & Main stem, branches, leaves & PCR \\
Toyon, Heteromeles arbutifolia (Rosaeceae) & Branches, leaves &
\end{tabular}

(Rizzo et al. 2002b; Garbelotto et al. 2001).

Initial work on the disease in California concentrated on oaks and oak mortality. However, in December 2000, we learned of a possible connection with an undescribed species of Phytophthora causing a stem and leaf blight on ornamental rhododendron and viburnium plants in Germany and the Netherlands (Rizzo et al. 2002b; Werres et al. 2001). A comparison of morphological characters and DNA sequences confirmed that the California and European pathogens were the same species of Phytophthora (Rizzo et al. 2002b). The European Phytophthora was eventually described as

P. ramorum (Werres et al. 2001) and this name was applied to the California oak pathogen (Rizzo et al. 2002b).

The finding of $P$. ramorum on rhododendron in Europe led us to hypothesize that its host range in California's natural forests was much greater than previously suspected. Using the symptoms described for three affected oak species (Quercus spp. [Q. kellogii, Q. agrifolia, $Q$. parvula var. shrevei]), tanoak (Lithocarpus densiflora) and rhododendron as a guide, we examined and sampled leaves and stems of tree and shrub species on numerous sites with oak mortality in California. In addition to the original four host species in the oak family (Fagaceae), we have now identified an additional 13 species from 10 plant families as hosts for P. ramorum throughout its range in California forests (table 1). Our data indicates that nearly all of the main tree species, including the coniferous timber species coast redwood (Sequoia sempervirens) and Douglas fir (Pseudotsuga menziesii), in mixedevergreen and redwood-tanoak forest types may be hosts for $P$. ramorum. Oaks in the subgenus Quercus (such as the white oaks) still appear to be unaffected by P. ramorum. Understory shrubs - such as manzanita (Arctostaphylos manzanita), toyon (Heteromeles arbutifolia), coffeeberry (Rhamnus californica) and honeysuckle (Lonicera hispidula) - are also hosts for P. ramorum.

\section{DNA aids in new-host discovery}

Field diagnosis of $P$. ramorum was initially attempted via direct isolation from symptomatic plant tissue. Phytophthora species, however, are often difficult to culture from plants, which may lead to false-negative isolations and misdiagnoses. Our DNA-based

diagnosis consisted of a process including: 1) freeze-drying of samples, 2) grinding of infected plant tissue and DNA extraction, and 3) amplification of $P$. ramorum DNA using the polymerase chain reaction (PCR). Once amplified, the DNA can be analyzed in a variety of ways to confirm that it belongs to the target species. Four specific PCR primers were developed based on sequences of the internal transcribed spacer (ITS) of nuclear ribosomal DNA unique to P. ramorum (Garbelotto et al. 2002). Two new protocols were also developed to eliminate cross-reactivity with various other species.

Overall, we found direct PCR amplification from symptomatic plant tissue to be more sensitive and reliable than culturing for initial detection of $P$. ramorum. Of the 13 non-oak host species we have identified in California, 10 were first detected this method (table 1). Although cultures of

$P$. ramorum have been obtained from all but one host species, the time period necessary to identify its expanded host range was considerably shortened by the use of species-specific molecular primers.

\section{Pathogen evaluated in hosts}

Isolation of $P$. ramorum from symptomatic plants was the first step in determining the pathogenic role played by this microbe on new hosts. However, association between symptoms and the presence of $P$. ramorum does not necessarily imply that this microbe plays a primary causal role. Rather,

P. ramorum may simply be an opportunistic colonizer of plants diseased by other agents. We conducted controlled experiments to further test pathogenicity between May 2001 and May 2002. Healthy plants were challenged with the pathogen, and the development of symptoms was described and quantified (Rizzo et al. 2002a). The process, known as Koch's postulate, ends with the successful reisolation of the microorganism from artificially infected plant tissue. Because most hosts were tested in separate trials, a comparison of susceptibility levels across hosts is not appropriate, and trial results for each host were analyzed independently.

For most experiments, three genetically different isolates of $P$. ramorum were used: Pr-5 from tanoak, Pr-6 from coast live oak and Pr-52 from rhododendron. Foliage inoculations of 2-to3-year-old plants were conducted by misting leaves with sterile distilled water and then pinning inoculum plugs to the upper surface of leaves. Sterile agar plugs were used as controls. A plastic bag was then placed over the individual leaves and misted again with sterile distilled water before sealing. Each trial generally consisted of 10 leaves per host species per isolate, plus controls. In all trials, seedlings were incubated for 2 weeks in a greenhouse that was maintained at $68^{\circ} \mathrm{F}$ to $75^{\circ} \mathrm{F}\left(20^{\circ} \mathrm{C}\right.$ to $\left.24^{\circ} \mathrm{C}\right)$. For each trial, we recorded symptoms, measured lesion length and width and plated pieces 
of stems or leaves on the selective Phytophthora growth medium PARP to verify presence or absence of P. ramorum. All leaf inoculations were conducted at least twice.

Methods for stem inoculations have been previously described (Rizzo et al. 2002b). Seedlings (stem diameter approximately 1 centimeter) of coast redwood and Douglas fir were inoculated with isolate Pr-52 in two separate trials started in January (five seedlings per treatments) and March 2002 (10 seedlings per treatment). Both trials lasted 6 weeks.

All data was analyzed by ANOVA using the software program JMP (SAS Institute Inc., Cary, NC, 1995). In all cases, there were no significant differences between different isolates and the different trials, so data was combined for final analysis.

\section{Symptoms and severity}

The symptoms of $P$. ramorum have only been observed on aboveground plant parts such as leaves, branches and stems, regardless of the host (table 1). In several instances, stem lesions end at the soil line. Although P. ramorum is deadly on certain oaks (Quercus spp.) and tanoak, disease progression and the extent of damage on individual plants of most non-oak hosts is not well characterized yet.

On several ericaceous plant species, $P$. ramorum causes significant foliar blight and branch dieback (table 1). Death of madrone (Arbutus menziesii) saplings in less than 4 months was observed in the field (P.E. Maloney, unpublished data) and it is suspected that the pathogen can kill mature madrone trees. Death of mature rhododendrons (Rhododendron macrophyllum) has also been observed in Oregon (Goheen et al. 2002). On other hosts, such as bay laurel (Umbellularia californica), California buckeye (Aesculus californica) and big leaf maple (Acer macrophyllum), $P$. ramorum appears to be primarily a leaf pathogen with very limited stem infection. Leaf inoculations of all suspected hosts resulted in the formation of lesions, and $P$. ramorum was successfully reisolated from all inoculated hosts (table 2).

Coast redwood. Symptoms on coast

\begin{tabular}{|c|c|c|c|c|c|}
\hline \multicolumn{6}{|c|}{$\begin{array}{l}\text { TABLE 2. Pathogenicity of Phytophthora ramorum on leaves of native } \\
\text { California plant species; all have been found infected in the field }\end{array}$} \\
\hline \multirow[b]{2}{*}{ Host: common name (species) } & \multicolumn{3}{|c|}{ P. ramorum } & \multicolumn{2}{|c|}{ Control } \\
\hline & $\mathbf{N}$ & $\begin{array}{l}\text { Percent } \\
\text { reisolation }\end{array}$ & $\begin{array}{l}\text { Lesion } \\
\text { size, } \mathrm{mm}^{*} \\
\text { (range) }\end{array}$ & $\mathbf{N}$ & $\begin{array}{l}\text { Lesion } \\
\text { size, } \mathrm{mm}^{*} \\
\text { (range) }\end{array}$ \\
\hline $\begin{array}{l}\text { Bay laurel/Oregon myrtle } \\
\text { (Umbellularia californica) }\end{array}$ & 28 & 100 & $\begin{array}{c}5 \\
(0-15)\end{array}$ & 8 & $\begin{array}{c}1.1 \\
(0-2)\end{array}$ \\
\hline $\begin{array}{l}\text { Big leaf maple } \\
\text { (Acer macrophyllum) }\end{array}$ & 42 & 100 & $\begin{array}{c}19.9 \\
(1-45)\end{array}$ & 12 & $\begin{array}{c}2.7 \\
(0-6)\end{array}$ \\
\hline $\begin{array}{l}\text { California black oak } \\
\text { (Quercus kellogii) }\end{array}$ & 15 & 100 & $\begin{array}{c}4.9 \\
(1-14)\end{array}$ & 6 & $\begin{array}{c}2.6 \\
(1-3)\end{array}$ \\
\hline $\begin{array}{l}\text { California buckeye } \\
\text { (Aesculus californica) }\end{array}$ & 48 & 94 & $\begin{array}{c}13.6 \\
(4.5-29)\end{array}$ & 18 & $\begin{array}{c}2.5 \\
(0-9)\end{array}$ \\
\hline $\begin{array}{l}\text { Coast live oak } \\
\text { (Quercus agrifolia) }\end{array}$ & 18 & 100 & $\begin{array}{c}2.1 \\
(1-4)\end{array}$ & 6 & $\begin{array}{c}1.6 \\
(1-2)\end{array}$ \\
\hline $\begin{array}{l}\text { Coast redwoodt } \\
\text { (Sequoia sempervirens) }\end{array}$ & 56 & 43 & $\begin{array}{c}4.9 \\
(1-20)\end{array}$ & 19 & $\begin{array}{c}1.6 \\
(1-3)\end{array}$ \\
\hline Seedlings & 20 & 100 & $\begin{array}{c}13.7 \\
(4-21)\end{array}$ & 20 & $\begin{array}{c}6.2 \\
(0-11)\end{array}$ \\
\hline $\begin{array}{l}\text { Coffeeberry } \\
\text { (Rhamnus californica) }\end{array}$ & 30 & 30 & $\begin{array}{c}4.4 \\
(1-15) \\
\end{array}$ & 10 & $\begin{array}{c}2.1 \\
(1-3)\end{array}$ \\
\hline $\begin{array}{l}\text { Douglas fir } ¥ \\
\text { (Pseudotsuga menziesii) }\end{array}$ & 58 & 47 & $\begin{array}{c}2.01 \\
(1-12)\end{array}$ & 15 & $\begin{array}{c}1 \\
(1)\end{array}$ \\
\hline Seedlings & 20 & 75 & $\begin{array}{c}38 \\
(12-64) \\
\end{array}$ & 20 & $\begin{array}{c}9 \\
(0-16) \\
\end{array}$ \\
\hline $\begin{array}{l}\text { Evergreen huckleberry§ } \\
\text { (Vaccinium ovatum) }\end{array}$ & 57 & 84 & $\begin{array}{c}15.3 \\
(3-22)\end{array}$ & 20 & $\begin{array}{c}2.0 \\
(1-13)\end{array}$ \\
\hline $\begin{array}{l}\text { Madrone } \\
\text { (Arbutus menziesii) }\end{array}$ & 18 & 100 & $\begin{array}{c}26.9 \\
(15-47)\end{array}$ & 6 & $\begin{array}{c}3.5 \\
(1-10)\end{array}$ \\
\hline $\begin{array}{l}\text { Manzanitaף } \\
\text { (Arctostaphylos manzanita) }\end{array}$ & 101 & 82 & $\begin{array}{c}10.6 \\
(1-23)\end{array}$ & 34 & $\begin{array}{c}2.1 \\
(1-6)\end{array}$ \\
\hline $\begin{array}{l}\text { Tanoak } \\
\text { (Lithocarpus densiflorus) }\end{array}$ & 18 & 100 & $\begin{array}{c}34.5 \\
(25-48)\end{array}$ & 6 & $\begin{array}{c}2.0 \\
(1-4)\end{array}$ \\
\hline $\begin{array}{l}\text { Toyon } \\
\text { (Heteromeles arbutifolia) }\end{array}$ & 44 & 72 & $\begin{array}{c}5.4 \\
(1-10)\end{array}$ & 16 & $\begin{array}{c}2.3 \\
(1-4)\end{array}$ \\
\hline \multicolumn{6}{|c|}{$\begin{array}{l}\text { * The average of lesion length and width } 14 \text { days after inoculation, except for coast redwood and Douglas fir, where it } \\
\text { only the length. Mean lesion lengths of } P \text {. ramorum were significantly greater on all hosts, with the exception of coast } \\
\text { live oak and Douglas fir, than those of control inoculations at } P<0.05 \text { based on ANOVA with contrasts. }\end{array}$} \\
\hline \multicolumn{6}{|c|}{$\begin{array}{l}\text { Tifteen inoculations of individual leaves led to discoloration of two or more adjacent leaves. On one inoculation, } \\
60 \mathrm{~mm} \text { of the adjacent stem was killed. }\end{array}$} \\
\hline \multicolumn{6}{|c|}{$\begin{array}{l}\text { Twenty-six of } 58 \text { single-leaf inoculations resulted in lesions of } 17-85 \mathrm{~mm} \text { long on adjacent branches ( } 5 \mathrm{~mm} \text { diameter) } \\
\text { even though the lesion length on the inoculated needle was } 1 \mathrm{~mm} \text { and apparently not connected to the longer stem } \\
\text { lesions. P. ramorum was recovered from } 13 \text { of these branch lesions. }\end{array}$} \\
\hline \multicolumn{6}{|c|}{$\begin{array}{l}\text { § Typical leaf lengths were } 15-20 \mathrm{~mm} \text {; entire leaves turned black on } 72 \% \text { of inoculations. On three inoculated leaves, } \\
\text { P. ramorum moved into the stems and caused lesions of } 30-50 \mathrm{~mm} \text { length. }\end{array}$} \\
\hline \multicolumn{6}{|c|}{$\begin{array}{l}\text { I Typical leaf lengths were } 15-20 \mathrm{~mm} \text {; entire leaves turned black on } 33 \% \text { of inoculations. On six inoculations, } \\
\text { P. ramorum grew through petioles and caused branch cankers of } 35-55 \mathrm{~mm} \text { on the main stem. }\end{array}$} \\
\hline
\end{tabular}

redwood are associated with saplings and basal sprouts on large trees. On saplings, $P$. ramorum causes discoloration of needles and cankers on small branches, resulting in an overall decline in tree vigor. The pathogen was isolated from the needles and small branches of 11 coast redwood saplings - about 1 to 6 inches ( 2 to 15 centimeters) in diameter - at two locations (Jack London State Park in Sonoma County and Henry Cowell State Park in Santa Cruz County). Distinct purple-colored lesions were observed on sprouts in the field and apparently lead to death of the shoots. P. ramorum was detected using the PCR diagnostic test from 12 of 90 symptomatic basal sprouts collected at seven locations spanning the known geographic range of $P$. ramorum in coastal California. While it appears that $P$. ramorum may be relatively abundant at these sites on coast redwood, the results also indicate that other causes of sprout mortality may be occurring. Greenhouse inoculations of coast redwood stems and leaves caused lesions similar to those observed in the field (table 2). In 


\section{The broad host range of $\mathrm{P}$. ramorum, the variability of symptoms among different hosts and the ability of the pathogen to disperse by air suggests that it may have the potential to cause long-term, landscape level changes in California forests.}

addition, extensive discoloration of the xylem was noted in sapling inoculations (data not shown).

The importance of $P$. ramorum in the dieback and death of mature coast redwood trees is still uncertain. In January 2002, the dieback of a mature coast redwood in an urban setting in Marin County was reported in the press and attributed by a local arborist to infection by $P$. ramorum. This diagnosis was conducted by a private laboratory and based on detection of a Phytophthora species using a nonspecific immunoassay (ELISA). We have confirmed that $P$. ramorum was present in the discolored xylem of the stump of the tree using direct PCR amplification and DNA sequencing. We were unable to directly isolate the pathogen from the discolored tissue, nor bait the pathogen from bark or soil samples taken from the base of the tree. This tree was affected by a concrete patio and driveway and had extensive root rot by two unidentified wood-decay fungi and by a root pathogen known as the oak root fungus or honey mushroom (Armillaria mellea). The role of $P$. ramorum in the development of dieback symptoms on this tree is difficult to determine because of the presence of these other pathogens and abiotic factors. Three other large urban redwood trees in Marin County reported in the popular press to be associated with $P$. ramorum were negative for the pathogen both by PCR analysis and culturing, although all of these trees had extensive decay caused by an unidentified canker rot fungus and

A. mellea. We have not observed unusual mortality or disease symptoms of overstory coast redwood in natural forests (Maloney et al. 2002).

Douglas fir. The impact of $P$. ramorum infection on Douglas fir is also not yet clear (Davidson, Garbelotto et al. 2002). We recovered the pathogen from infected branch tips of Douglas fir at a single location in Sonoma County. Cankers on small branches 0.2 to 0.4 inches ( 0.5 to 1 centimeters) in diameter resulted in wilting and dieback of branches and needles. Greenhouse inoculations of individual Douglas fir leaves resulted in discoloration of inoculated leaves and the subsequent dieback of adjacent leaves and twigs. Inoculations of stems resulted in resinosis from the bark, cambial necrosis and dieback, and discoloration of foliage (table 2). Symptoms on Douglas fir do not appear to be common in the field at this time and have not been observed on overstory trees.

\section{P. ramorum epidemiology in Calif.}

Across the range of known hosts, we can distinguish two different types of diseases: nonlethal foliar and twig infections, and lethal branch or stem infections. Foliar infections play a key role in the epidemiology of $P$. ramorum by serving as a source of inoculum, which is then spread aerially through rain splash (Davidson, Garbelotto et al. 2002). The most likely dispersal propagules of $P$. ramorum, sporangia and chlamydospores, are readily produced on foliage (particularly of bay laurel/Oregon myrtle and Rhododendron spp.), but we have yet to find

them on infected oak bark. Therefore, $P$. ramorum epidemics in California oak forests may be driven by the presence and susceptibility of associated plant hosts, not the oaks themselves.

Two recent studies have reported a significant association between the presence of bay laurel/Oregon myrtle trees and $P$. ramorum infection on certain oaks (Quercus spp.)(Swiecki and Bernhardt 2002; Kelly and Meentemeyer 2002). Likewise, our preliminary studies indicate that foliar host infection may precede infection of oaks (Quercus spp.) and tanoak on a site. We hypothesize that $P$. ramorum may need to produce inoculum on the leaves of these associated hosts to serve as a springboard to oak species. Hosts with relatively small lesions may be especially important in the transmission biology of $P$. ramorum because such lesions do not kill leaves but can support abundant sporulation for extended periods of time.

\section{Multiple plant hosts and epidem-}

ics. The hypothesis that $P$. ramorum may need multiple plant hosts to cause epidemics is also supported by the results of molecular genetic analyses of $P$. ramorum populations. Genetic fingerprinting on a number of California, Oregon and
European isolates is under way using a technique called amplified fragment length polymorphisms (AFLPs)(Vos et al. 1995). Recent studies (Garbelotto et al. 2001; unpublished data) reveal that a single individual of $P$. ramorum has been clonally reproducing and is responsible for over $80 \%$ of all infections in California and Oregon. The genetic analysis confirms that the same individual is capable of infecting all hosts. This result is significant because identical-looking pathogens isolated from different hosts may represent undistinguishable but genetically different microorganisms. In addition to the results stemming from the genetic analyses, inoculation of all hosts with cultures isolated from oaks and rhododendron always resulted in typical disease symptoms (table 2 ). Such data strongly suggests that the pathogen moves from one host to another with no evidence of host specificity for different isolates.

The establishment and spread of $P$. ramorum may be mediated by foliar infections on a variety of hosts. Furthermore, both reproductive (such as sporangia) and resting (such aschlamydospores) structures have been found to accumulate in soil and water (Davidson, Rizzo et al. 2002). Preliminary results indicate that plant material can become infected if placed in contact with infested soil or water, which are likely to play an important role both in the natural and artificial transmission of this pathogen.

Temperature and moisture. The presence of $P$. ramorum has been confirmed in 12 California counties: (from north to south) Humboldt, Mendocino, Sonoma, Napa, Solano, Marin, Contra Costa, Alameda, San Mateo, Santa Clara, Santa Cruz and Monterey. The levels of infestation vary significantly among counties. While large areas within Marin, Santa Cruz, Sonoma and Monterey counties are severely affected, the disease is still sporadically present in all other counties. It has been hypothesized that $P$. ramorum may thrive in cool and moist environments; if so, the extent and severity of diseases that it causes may be correlated to temperature and moisture conditions. 


\section{Natural spread of the disease in California will be affected by weather patterns and by presence of genetic resistance in susceptible hosts.}

P. ramorum growth is optimal at temperatures between $64.4^{\circ} \mathrm{F}$ and $71.6^{\circ} \mathrm{F}$ $\left(18^{\circ} \mathrm{C}\right.$ and $22^{\circ} \mathrm{C}$ )(Werres et al. 2001). Laboratory trials recently showed that the infection rate for bay leaves may average $92 \%$ at $18^{\circ} \mathrm{C}$, but only $50 \%$ and $37 \%$ at the less favorable temperatures of $53.6^{\circ} \mathrm{F}$ and $86^{\circ} \mathrm{F}\left(12^{\circ} \mathrm{C}\right.$ and $\left.30^{\circ} \mathrm{C}\right)$, respectively (unpublished data). Besides cool temperatures, free water must be present on plant surfaces for efficient infection. P. ramorum produces infectious propagules called zoospores, which need to swim in a liquid environment in order to reach a susceptible host. Preliminary studies indicate that a minimum of 6 to 12 hours of free-standing water is required for infection of bay leaves. Rain, fog or dew accumulation may result in the formation of a persistent film of water on plant surfaces.

Studies based on isolations of $P$. ramorum from infested soil indicate that pathogen activity starts after repeated precipitation events and peaks during spring months (J.M. Davidson and P.E. Maloney, unpublished data). Dry and warm weather in the summer and fall result in a sharp decrease and eventually complete arrest of $P$. ramorum activity in soil. Activity of the pathogen on living plants can be inferred by the isolation success of $P$. ramorum from symptomatic plants in the field. Results from 2 years of collections indicated that isolation success from living plants decreases sharply in the summer and fall without ever reaching zero. This is probably because $P$. ramorum is growing in a protected environment within the plant tissue.

Based on the data currently available, the intensity of the disease should be positively correlated with cool and
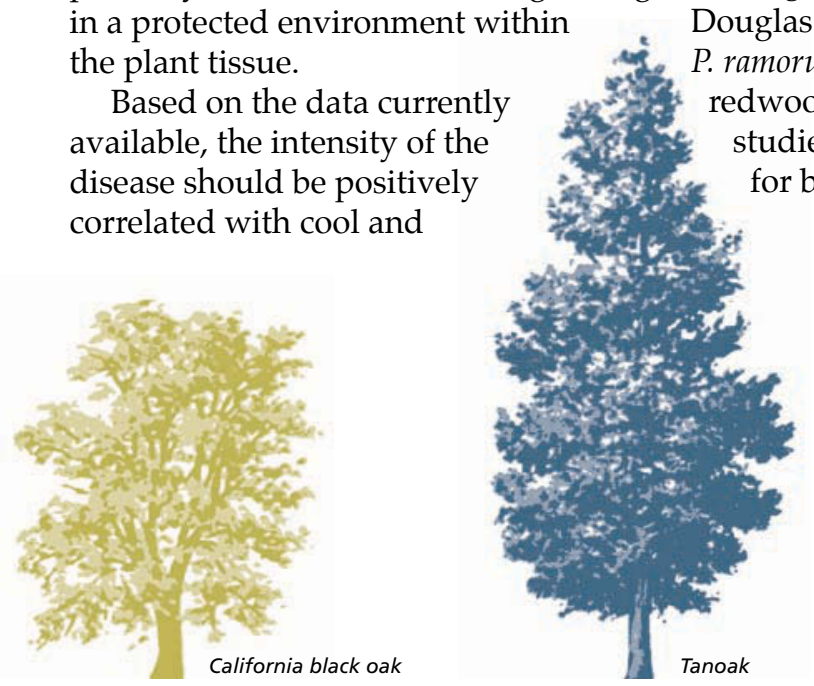

moist conditions. Further research, however, is under way to precisely quantify the parameters associated with disease expression.

\section{Landscape-level forest changes}

A broad host range and predominant clonal reproductive strategy are not unprecedented in the genus Phytophthora (Erwin and Ribeiro 1996). Phytophthora cinnamomi is known to reproduce mostly clonally and to attack more than 2,000 plant species; it has caused significant ecological damage to forest ecosystems in Australia, Europe and North America. The broad host range of P. ramorum, the variability of symptoms among different hosts and the ability of the pathogen to disperse by air, suggest that it may also have the potential to cause similar, long-term, landscapelevel changes in California forests. Hosts for $P$. ramorum include canopy trees and understory shrubs. The longterm consequences regarding mortality for non-oak hosts are unknown at this time. However, branch dieback on these non-oak hosts may affect leaf and seed production, negatively impact growth and regeneration, and predispose the plant to attacks by other pathogens and insects. Sublethal infections of non-oak hosts may also allow P. ramorum to persist indefinitely in infested forests and affect the success of future regeneration and restoration efforts. It is unclear at this time what the long-term consequences will be for the harvesting and regeneration of coast redwood and Douglas fir. However, the observation of ramorum in the xylem of a large coast dwood, the results of the inoculation tudies or both conifers, and the detection of $P$. ramorum in dying sprouts and branches suggest that the situation requires more extensive research.

The apparent limited gene pool of P. ramorum in North America, combined with the extreme susceptibility of some hosts and the pathogen's limited known area of distribution, suggest an introduced organism, but its actual origin and global genetic structure remain unknown. Faced with uncertainty about the origin, distribution and host range of $P$. ramorum, and because many of the known hosts have ranges well beyond California, the United States, Canada, United Kingdom and South Korea have implemented quarantines against movement of certain plant material and / or soil from California and Oregon. The United States has implemented similar restrictions on the movement of potentially affected plant material from Europe. The discovery that even small foliar lesions may potentially be epidemiologically important, combined with the difficulties encountered in culturing the pathogen, is proving to be challenging from a regulatory and monitoring perspective. The use of the DNA-based diagnostic test outlined here offers a reliable approach to detect $P$. ramorum, follow its movement and ultimately understand its biology.

While regulatory actions may prevent the spread of $P$. ramorum to new areas, California coastal forest ecosystems are currently witnessing an expansion of the infestation. Natural spread of the disease in California will be affected by weather patterns and by presence of genetic resistance in susceptible hosts. Preliminary studies (Dodd and Garbelotto, unpublished data) indicate that individuals of both bay laurel and coast
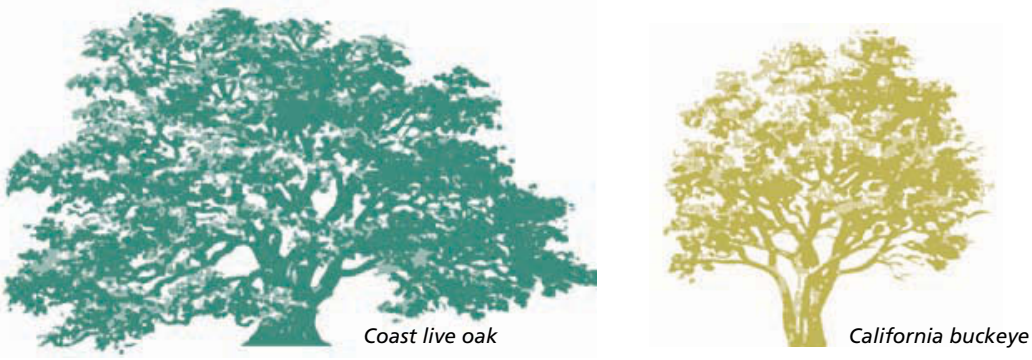


\section{In order to assist the natural recovery of the ecosystem \\ it is essential to fully understand the pathogen's biology and identify \\ forest management approaches that can hinder its spread.}

live oak display different levels of disease resistance.

In order to assist the natural recovery of California's forest ecosystems, it is essential to fully understand the pathogen's biology and identify management approaches that can hinder its spread. In Western Australia (Hardy et al. 2001), targeted chemical treatments may have significantly slowed down the spread of the disease. Results from a series of ongoing studies (Garbelotto, Rizzo and Marais 2002) indicate that it may be possible to employ chemical treatments to prevent infection on individual trees (see p. 6). The availability of such treatments, and their careful application, may add a useful tool to an integrated control approach for this ecosystemlevel disease.

\section{Garbelotto is Forest Pathology Exten-} sion Specialist and Adjunct Professor, Department of Environmental Science, Policy and Management (ESPM), UC Berkeley; J.M. Davidson is Postdoctoral Researcher, Department of Plant Pathology, UC Davis and Research Associate, Pacific Southwest Research Station, USDA Forest Service, Berkeley;

K. Ivors is Postdoctoral Researcher, ESPM, UC Berkeley; P.E. Maloney is Postdoctoral Researcher, Department of Plant Pathology, UC Davis; D. Hüberli is Postdoctoral Researcher, ESPM, UC Berkeley; S.T. Koike is Farm Advisor, UC Cooperative Extension, Salinas; and D.M. Rizzo is Associate Professor, Department of Plant Pathology, UC Davis. This research was supported by grants from the USDA Forest Service and the

Gordon and Betty Moore Foundation. We greatly appreciate the technical assistance of A. Wickland, S. Murphy, S. Kane, C. Jensen, G. Slaughter, D. Schmidt, J. Tse, T. Harnik, K. Hayden, A. Smith, W. Van Sant and D. Henderson. The European isolates were provided by $S$. Werres, with additional samples from E. Hansen, K. Bovero, R. Gross, S. Tjosvold and P. Mordike. Comments on the manuscript by T. Bruns and E. Hansen were greatly appreciated.

\section{References}

Davidson JM, Garbelotto M, Koike ST, Rizzo DM. 2002. First report of Phytophthora ramorum on Douglas-fir in California. Plant Dis 86:1274.

Davidson JM, Rizzo DM, Garbelotto M. 2002. Phytophthora ramorum and sudden oak death in California: II. Pathogen transmission and survival. In: Standiford R, McCreary D, Purcell KB (eds.). Proc 5th Oak Symposium: Oaks in California's Changing Landscape. Oct. 22-5, 2001. San Diego, CA. USDA Forest Service, Gen. Tech. PSW-GTR184. p 741-9.

Erwin DC, Ribeiro OK. 1996. Phytophthora Diseases Worldwide. St. Paul, MN: APS Press.

Garbelotto M, Rizzo DM, Hayden K, et al. 2002. Phytophthora ramorum and sudden oak death in California: III. Pathogen genetics. In: Standiford R, McCreary D, Purcell KB (eds.). Proc 5th Oak Symposium: Oaks in California's Changing Landscape. Oct. 22-5, 2001. San Diego, CA. USDA Forest Service, Gen. Tech. PSW-GTR-184. p 765-74.

Garbelotto M, Rizzo DM, Marais L. 2002. Phytophthora ramorum and sudden oak death in California: IV. Chemical control. In: Standiford R, McCreary D, Purcell KB (eds.). Proc 5th Oak Symposium: Oaks in California's Changing Landscape. Oct. 22-5, 2001. San Diego, CA. USDA Forest Service, Gen. Tech. PSW-GTR-184. p 811-8.

Garbelotto M, Svihra P, Rizzo DM. 2001. Sudden oak death syndrome fells three oak species. Cal Ag 55(1):9-19.

Goheen EM, Hansen EM, Kanaskie A, et al. 2002. Sudden oak death caused by Phytoph-thora ramorum in Oregon. Plant Dis 86:441.

Hardy G, Barrett S, Shearer BL. 2001. The
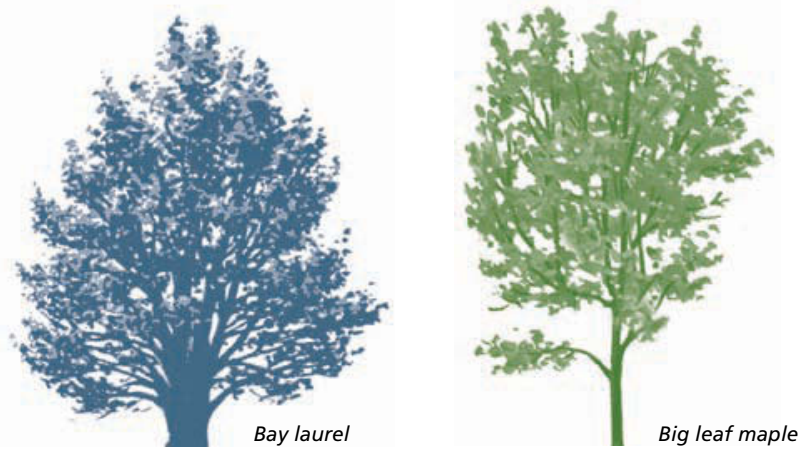

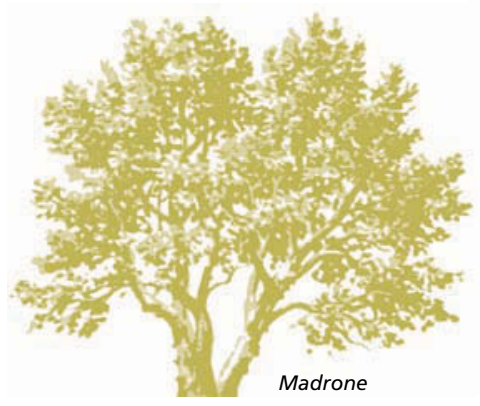

future of phosphite as a fungicide to control the soilborne plant pathogen Phytophthora cinnamomi in natural ecosystems. Austra-lasian Plant Pathol 30(2):133-9.

Kelly NM, Meentemeyer R. 2002. Landscape dynamics of the spread of sudden oak death. Photo Eng Rem Sens 68:1001-9.

Maloney PE, Rizzo DM, Koike ST, et al. 2002. First report of Phytophthora ramorum on coast redwood in California. Plant Dis 86:1274.

Rizzo DM, Garbelotto M, Davidson JM, et al. 2002a. Phytophthora ramorum and sudden oak death in California: I. Host relationships. In: Standiford R, McCreary D, Purcell KB (eds.). Proc 5th Oak Symposium: Oaks in California's Changing Landscape. Oct. 22-5, 2001. San Diego, CA. USDA Forest Service, Gen. Tech. PSW-GTR-184. p 733-40.

Rizzo DM, Garbelotto M, Davidson JM, et al. 2002b. Phytophthora ramorum as the cause of extensive mortality of Quercus spp. and Lithocarpus densiflorus in California. Plant Dis 86:205-14.

Swiecki TJ, Bernhardt E. 2002. Evaluation of stem water potential and other tree and stand variables as risk factors for Phytophthora ramorum canker development in coast live oak. In: Standiford R, McCreary D, Purcell KB (eds.). Proc 5th Oak Symposium: Oaks in California's Changing Landscape. Oct. 22-5, 2001. San Diego, CA. USDA Forest Service, Gen. Tech. PSW-GTR-184. p 787-98.

Vos P, Hogers R, Bleeker M, et al. 1995. AFLP: A new technique for DNA fingerprinting. Nucleic Acids Res 23(21):4407-14.

Werres S, Marwitz R, Man In'T Veld WA, et al. 2001. Phytophthora ramorum sp. nov., a new pathogen on Rhododendron and $\mathrm{Vi}$ burnum. Mycol Res 105:1155.

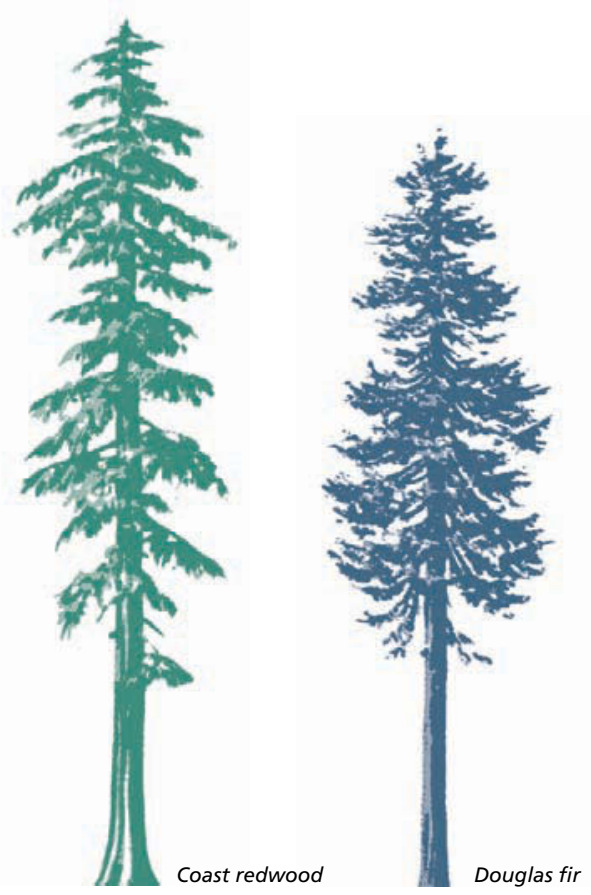

